Joanna Sapa

Uniwersytet Śląski

j.sapa@wp.pl

\title{
„Człowiek siedzi przy stole...”. Codzienność w Psalmie codziennym Tadeusza Nowaka
}

\author{
"A Man is Sitting at a Table..." Everyday Life in Psalm codzienny [Everyday Psalm] \\ by Tadeusz Nowak
}

\begin{abstract}
Tadeusz Nowak, the author of Psalm codzienny [Everyday Psalm] not only plays the role of a continuator of this genre in the second half of the $20^{\text {th }}$ century, but also is a restorer of the form. The world presented in his stanzaic, regular poems is permeated by pain and undeserved but inevitable suffering. On the other hand, in his poems it is difficult to find a clear and typical elements of Biblical psalms: the feeling of stability and care, trust or faith. However, the article is not only an attempt at classifying this interpretatively difficult poem according to genre, but also a study of the rural reality of the mid- $20^{\text {th }}$ century (particular motifs are described in separate sections). Nowak combines the Biblical tradition with folklore, draws on the rich symbolism of numbers, refers to the Decalogue and Commandments of the Church, as well as looks deep inside the human and doesn't shy away from showing their flaws and faults. Hence, both in the article and in the poem the refrain recurs again and again: "next to the man there lies/ an angel tied with a wire/ a herring skeleton glass/ next to the man there lies/ a crucified god." These apparently insignificant mundane objects, which (apparently) do not match the sphere of the sacred, gain new senses in Nowak's poem. The simple reality and that "folkloric clutter" cease to be any cultural "junk" and become rediscovered jewels of tradition.
\end{abstract}

Keywords: Tadeusz Nowak, psalm, everyday, mundane, Bible, folklore

Streszczenie: Tadeusz Nowak, autor Psalmu codziennego, z jednej strony pełni funkcję kontynuatora tego gatunku w drugiej połowie XX wieku, z drugiej - jest też odnowicielem formy. Świat ukazany w jego zwrotkowych regularnych wierszach okazuje się przeniknięty bólem i niezasłużonym, acz nieuchronnym, cierpieniem. Niemniej u Nowaka trudno znaleźć wyraźne, a typowe dla psalmów biblijnych poczucie stałości, opieki, zaufania, zawierzenia. Artykuł to jednak nie tylko próba zaklasyfikowania tego, trudnego w odczytaniu, utworu do konkretnego gatunku, lecz także studium o wiejskiej rzeczywistości z połowy ubiegłego stulecia (poszczególne wątki opisane są w kolejnych częściach). Nowak łączy bowiem tradycję biblijną z folklorem, czerpie z bogatej symboliki cyfr, sięga do dekalogu i przykazań kościelnych, a przy tym zagląda w głąb człowieka i nie waha się pokazać jego skaz i wad. 
Dlatego zarówno wierszu, jak i w artykule niezmiennie powraca refren: „obok człowieka leży/ związany drutem anioł/ szkielecik śledzia szkło/ obok człowieka leży/ ukrzyżowany Bóg”. Te, z pozoru nieważne codzienne przedmioty, które (pozornie) nie pasują do sfery sacrum, u Nowaka zyskują nowe sensy. Zwykła codzienność oraz owa „folklorystyczna rupieciarnia” przestają być swoistymi kulturowymi „odpadkami”, a stają się odkrywanymi na nowo skarbami tradycji.

Słowa kluczowe: Tadeusz Nowak, psalm, codzienność, Biblia, folklor

\section{Psalm codzienny}

Człowiek siedzi przy stole

z głową wspartą na rękach

W głowie człowieka dom

kwaterka wódki śledź

w głowie człowieka żona

kwaterka wódki śledź

w głowie człowieka dzieci

kwaterka wódki śledź

Obok człowieka leży

związany drutem anioł

szkielecik śledzia szkło

obok człowieka leży

ukrzyżowany Bóg

szkielecik śledzia szkło

obok człowieka leży

trzydzieści groszy reszty

szkielecik śledzia szkło

Człowiek siedzi przy stole

szkielecik śledzia szkło ${ }^{1}$.

\section{Problemy w zdefiniowaniu gatunku}

Psalmy zajmują w twórczości Tadeusza Nowaka miejsce szczególne: „z perspektywy czasu - pisze Stanisław Balbus - stanowią najbardziej rozpoznawalny przejaw [jego - przyp. J.S.] poezji. Są jej kwintesencją i - być może - osiąg-

${ }^{1}$ T. Nowak, Psalm codzienny [w:] tegoż, Wiersze wybrane, Warszawa 1978, s. 284. Wszystkie cytaty według tego wydania. 
nięciem szczytowym"2. Badacz zauważa ponadto, że w świecie wykreowanym przez XX-wiecznego poetę:

na początku był „Psalm” - słowo święte, wyrażające sakralno-mitologiczną jedność świata. Świat ów - jeszcze w czasach nazywanych przez mowę psalmiczną - zaczął się rozpadać i degenerować. Potem przekształcił się już jawnie w rzeczywistość naznaczoną piętnem (...), tj. mówiąc ściślej - ujawnił bezceremonialnie poecie takie właśnie swoje prawdziwe oblicze. Wraz z tym rozpadła się i zniknęła psalmodia poetycka; pozostał szept pacierzy i mamrotanie paciorków. A kiedy poeta podjął próbę powrotu do tonacji psalmicznej w odradzającym się ludzkim świecie, psalm okazał się już tylko prywatną, samotną pieśnią pośród bezsennych nocy. Pieśnią zmierzchu. Ale może i pieśnią nieokreślonej bliżej nadziei? ${ }^{3}$

Ksiądz Józef Sadzik w przedmowie do wydania Ksiag biblijnych... w tłumaczeniu Czesława Miłosza stawia jasną tezę, iż: „psalmy są nade wszystko fenomenem religijnym"4. W utworach tych źródłem oraz centrum życia jest wiara. W Biblii, co paradoksalne, nie ma jednak (w potocznym rozumieniu) ludzi wierzących. Ksiądz Sadzik pisze:

w Biblii ludzie nie wierzą w Boga, lecz wierzą Bogu. (...) Jeżeli uważnie wczytać się w psalmy, można zdać sobie sprawę, że ludzie nie wierzą tam w nagrody po śmierci. (...) W psalmach wierzy się Bogu, ponieważ jest Bogiem, a nie dlatego, że nagradza po śmiercis.

Owa wyjątkowość psalmu jest być może przyczyną tego, iż ułożenie pełnej definicji tej formy lirycznej okazuje się bardzo trudne - jeśli nie niewykonalne. Henryk Pustkowski, autor hasła w Stowniku rodzajów i gatunków literackich, pisze, że określenie konturu tego gatunku możliwe jest właściwie tylko dzięki detrakcji, to jest oddzieleniu „psalmu” od hymnu i innych gatunków sapiencjalnych ${ }^{6}$.

Inną drogą, zmierzającą do zdefiniowania gatunku, jest analiza historyczna. Wtedy na plan pierwszy wysunie się stwierdzenie, że psalmy stanowią zbiór stu pięćdziesięciu utworów, który:

2 S. Balbus, Tadeusza Nowaka psalmy mitosne [w:] Nowy Nowak (Tadeusz), red. J. Olejniczak, R. Knapek, Katowice 2016, s. 29.

${ }^{3}$ Tenże, Poezja $w$ czasie marnym (O metafizyce i historiozofii poezji Tadeusza Nowaka), Kraków 1992, s. 101, http://biblioteka.kijowski.pl/nowak\%20tadeusz/balbus\%20o\%20nowaku.pdf, dostęp: 15.04.2017.

${ }^{4}$ J. Sadzik, O psalmach [w:] C. Miłosz, Ksiegi biblijne. Przektady z języka greckiego $i$ hebrajskiego, Kraków 2003, s. 12.

5 Tamże, s. 14-15.

${ }^{6}$ H. Pustkowski, Psalm [w:] Stownik rodzajów i gatunków literackich, red. G. Gazda, S. Tynecka-Makowska, Kraków 2006, s. 620. 
podzielono na pięć ksiąg. Powstawały one między XI-III w. p.n.e. (...). Tekst w języku łacińskim ustalony przez św. Hieronima w Psalterium Galicum (IV w. n.e.) wszedł do Wulgaty, kanonicznej wersji Pisma św. obowiązującej w Kościele katolickim ${ }^{7}$.

Nadal niewiadomą pozostaje jednak dokładna data powstania poszczególnych psalmów. Nie znamy także ich autorów, a teza, iż to król Dawid napisał cały psałterz, została ostatecznie odrzucona ${ }^{8}$.

Badania etymologiczne również nie dają pełnej odpowiedzi na pytanie, czym są psalmy. Przyjmuje się, co prawda, że nazwa „psalm” pochodzi od greckiego instrumentu strunowego odpowiadającego hebrajskiemu określeniu harfy. Natomiast „zbiór psalmów oznaczony był w języku hebrajskim jako Sefer Tehilim - od rdzenia hil 'chwalić, oznaczałby więc księgę pieśni pochwalnych"”.

Czy można jednak traktować ten wyznacznik jako najważniejszy w rozpoznawaniu psalmów? A co, jeśli - tak jak na przykład w poezji XX wie$\mathrm{ku}-\mathrm{w}$ tytule utworu pojawia się słowo „psalm”, lecz sam tekst wydaje się bardzo odległy od pieśni pochwalnej? Czy należy wtedy zupełnie zignorować aluzję gatunkową i od razu przyjąć, że wiersz nie jest psalmem? Czy fakt, że wiersz dotyczy spraw ludzkich, a nie nieskończonych, wymazuje jego „psalmiczność"? A może wręcz przeciwnie?

Właśnie taki (niejednoznaczny) przypadek stanowi Psalm codzienny Tadeusza Nowaka. Poeta ten był nie tylko kontynuatorem tego gatunku (obok Józefa Czechowicza, Krzysztofa Kamila Baczyńskiego czy Ernesta Brylla), lecz także odnowicielem formy. Tak komentuje to Stanisław Balbus:

Nowak (...) pisze zwrotkowe regularne i rymowane wiersze, które uporczywie nazywa w tytule psalmami, choć z formą gatunkową psalmów mają dość niewiele wspólnego. (...) A jednak domaga się, aby wiersze te czytać właśnie jako psalmy ${ }^{10}$.

Nie bez powodu przecież ukazany w nich świat jest przeniknięty bólem i niezasłużonym, acz nieuchronnym, cierpieniem. Poza tym psalmy Nowaka, tak jak te biblijne:

będąc „dowodem osobistym” konkretnej jednostki i konkretnego narodu, są jednocześnie niezrównanym wyrazem uniwersalizmu rzeczywistości ludzkiej. Ów pa-

7 Tamże.

8 J. Sadzik, dz. cyt., s. 27.

9 H. Pustkowski, dz. cyt., s. 620.

${ }^{10}$ S. Balbus, Zagtada gatunków [w:] Polska genologia literacka, red. D. Ostaszewska, R. Cudak, Warszawa 2007, s. 164-165. 
radoks, owa sprzeczność konkretu i powszechności jest w psalmach pozorna - jak zresztą w każdym wielkim dziele ${ }^{11}$.

Niemniej u Nowaka trudno znaleźć wyraźne, a typowe dla psalmów z Biblii: „poczucie stałości, solidności, pewności, mocy (...), poczucie opieki, zaufania, zawierzenia" 12 .

\section{Siedem i sześć}

Psalm codzienny jest bardzo regularny. Liczba zgłosek w poszczególnych wersach strofy pierwszej to: 7-7-6-6-7-6-7-6; w strofie drugiej: 7-7-6-7-6-6-7-7-6. Dwuwers kończący wiersz ma zaś układ: 7-6.

Wybór takiego metrum nie wydaje się przypadkowy. Zwłaszcza że, jak pisze Jerzy Kwiatkowski w szkicu zatytułowanym Magia poezji, względem utworów Nowaka odnosimy wrażenie:

które z punktu widzenia analitycznego znajduje swoją motywację zarówno w konsekwencji, z jaką w poezji tej powracają pewne (...) obrazowe motywy (...) - jak $\mathrm{w}$ umiejętności stworzenia swoistego, jedynego w swoim rodzaju stopu: realiów, obrazowania, rytmiki. Inaczej mówiąc: umiejętność stworzenia oryginalnego poetyckiego języka, za pomocą którego poeta potrafi przekazać czytelnikowi te nawet elementy swojej psychiki, które niezupełnie jasno rysują się w jego świadomości ${ }^{13}$.

Nie bez znaczenia jest też szczególny sentyment, jakim Nowak już w dzieciństwie darzył Psalmy biblijne. Po latach tak pisał o swoich doświadczeniach:

Długo, bo aż do piętnastego roku życia, nie wiedziałem, że istnieje coś takiego, co zwie się wierszem. (...) I bez tej wiedzy truchlałem ze strachu, kiedy w kościele poczynano śpiewać pokutne psalmy ${ }^{14}$.

\section{I dalej:}

Nie mogłem przecież wiedzieć, bo w naszej wsi nikt o tym nie wiedział, że owe psalmy śpiewał niegdyśs król Dawid (...). Jakoż jeszcze wtedy sądziłem, że psalmy (...) zeszły z nieba na ręce i na usta świętych na podobieństwo złotego deszczu ${ }^{15}$.

${ }^{11}$ J. Sadzik, dz. cyt., s. 11.

12 Tamże, s. 14.

13 J. Kwiatkowski, Magia poezji (O poetach polskich XX wieku), Kraków 1995, s. 209.

14 T. Nowak, Mój wiersz, „Poglądy” 1963, nr 20, cyt. za: J. Brudnicki, Tadeusz Nowak, Warszawa 1978, s. 44.

15 Tamże. 
Symbolika cyfr, wyrażających liczbę zgłosek w kolejnych wersach Psalmu codziennego, jest niezwykle bogata. W Stowniku symboli Władysław Kopaliński podaje, że „siedem” ${ }^{16}$ od czasów pradawnych jest między innymi symbolem stworzenia, czasu oraz losu. Siedem to również suma dwu liczb szczęśliwych: trójki i czwórki, Nieba i Ziemi.

W Starym Testamencie siódemka występuje łącznie aż 11 razy $^{17}$. Według Księgi Rodzaju Bóg stworzył świat w ciagu tygodnia - stąd już w starożytnej Chaldei obowiązywał siedmiodniowy tydzień jako podstawowa miara czasu. Z kolei w nowotestamentowej Ewangelii wg Mateusza przeczytamy o siedmiu dziełach miłosierdzia: łaknącego nakarmić, spragnionego napoić, bezdomnego ugościć, nagiego przyodziać, chorego i więźnia nawiedzić; umarłego pochować $^{18}$.

Tradycja przekazuje nam wiarę w siedem darów ciała (wzrok, słuch, węch, smak, ruch, praca, rozmnażanie się) oraz siedem darów ducha (rozum, inteligencja, rada, męstwo, wiedza, prawość, bojaźń boża). Siódemka symbolizuje jednak także zło. Jak podaje Ksiegga przypowieści, siedem rzeczy, których nienawidzi Pan, to: „butne oczy, kłamliwy język, ręce, które przelewają krew niewinną, serce knujące złe myśli, nogi spieszące do złego, składanie fałszywego świadectwa i sianie niezgody między braćmi” ${ }^{19}$.

„Siedem” to ponadto znak oszukaństwa i uporu. W przysłowiu „od siedmiu boleści” mówimy o czymś lichym i bezwartościowym. W tradycji chrześcijańskiej istnieje także zapis dotyczący siedmiu grzechów głównych. Są to: pycha, chciwość, nieczystość, zazdrość, nieumiarkowanie w jedzeniu i piciu, gniew i lenistwo.

Jednocześnie jednak w Kościele katolickim wyznaje się wiarę w siedem sakramentów świętych: chrzest, bierzmowanie, sakrament ołtarza, sakrament pokuty, ostatnie namaszczenie, kapłaństwo, małżeństwo.

Cyfrę „sześć” ${ }^{20}$ natomiast w tradycji utożsamia się między innymi z odczuwaniem przyjemności. W symbolice chrześcijańskiej szóstka z jednej strony

16 W. Kopaliński, Siedem [w:] tegoż, Stownik symboli, Warszawa 1991, s. 379-382.

17 Por. na przykład Księga Jozuego (5, 8-20): „I stało się, jak Jozue rozkazał ludowi. Siedmiu kapłanów, niosących przed Panem siedem trąb z rogów baranich, wyruszyło grając na trąbach, Arka zaś Przymierza Pańskiego szła za nimi. Zbrojni wojownicy szli przed kapłanami, którzy grali na trąbach, a tylna straż szła za Arką, i tak posuwano się, stale grając na trąbach. (...) Gdy kapłani za siódmym razem zagrali na trąbach, Jozue zawołał do ludu: „Wznieście okrzyk wojenny, albowiem Pan daje miasto w moc waszą!« (...) Lud wzniósł okrzyk wojenny i zagrano na trąbach. Skoro tylko usłyszał lud dźwięk trąb, wzniósł gromki okrzyk wojenny i mury rozpadły się na miejscu. A lud wpadł do miasta, każdy wprost przed siebie, i tak zajęli miasto". Por. Księga Przypowieści $(24,16)$ : „Siedemkroć upadnie sprawiedliwy, a powstanie, lecz bezbożni w zło wpadną".

18 Por. Ewangelia wg świętego Mateusza (25, 35-36).

19 Por. Księga przypowieści (6, 16-19).

20 W. Kopaliński, dz. cyt., s. 413-414. 
jest święta, gdyż w sześć dni Bóg stworzył świat, z drugiej - złowieszcza, gdyż według Apokalipsy imię bestii wychodzącej z ziemi to, jak wiadomo, $666^{21}$.

„Sześć” to także ciało ludzkie: głowa, korpus i cztery kończyny. „Sześć” również jako dwuznaczność, związek ognia i wody, a więc duszy ludzkiej. Jest symbolem przeznaczeń mistycznych, zrównoważonej opozycji Stwórcy i stworzenia, z której wypłynąć może zarówno dążenie do złączenia się z bóstwem, jak i bunt przeciw niemu.

W tradycji znanych jest jeszcze sześć źródeł pokusy: pięć zmysłów i wola, a także sześć grzechów przeciw Duchowi Świętemu: zuchwałe grzeszenie w nadziei miłosierdzia boskiego; rozpacz albo zwątpienie o miłosierdziu bożym; sprzeciwianie się uznanej prawdzie; zazdrość o łaskę bożą bliźniego.

\section{„Człowiek siedzi przy stole...”}

Psalm codzienny, podobnie jak Psalmy biblijne, które w tytułach zawierają „wskazówki dotyczące gatunku psalmu, sposobu wykonywania, użytku liturgicznego etc."22, swym tytułem także sugeruje podjętą w tekście problematykę. W wierszu Nowaka:

Człowiek siedzi przy stole

$\mathrm{Z}$ głową wspartą na rękach.

To scena jak najzwyklejsza, znana każdemu i - jak chce tytuł - codzienna. Od niej wszystko się jednak zaczyna i - co znamienne - na niej kończy, by znów się rozpocząć...

Bohater siedzi przy stole. To czynność stała, niezmienna, podczas gdy wszystko inne - wspominane w myślach: dom, żona, dzieci, a także śledźl szkielecik śledzia, kwaterka wódki/ szkło, zdaje się krążyć w ciągle od nowa powtarzanym rytuale, niemającym ani wyraźnego początku, ani końca.

Ów rytuał - to życie widziane znad kieliszka. Życie w samej swej istocie, brutalne, odarte $\mathrm{z}$ wszelkich zasłon - po prostu takie, jakim jest naprawdę. Życie, którego miarą są: „kwaterka wódki” i „śledź”, cyklicznie - wraz z upływem czasu - zmieniające się w „szkielecik śledzia” i „szkło”. To wiejska rzeczywistość z połowy XX wieku. Nowak bowiem - jak pisze Stanisław Balbus posiadał „swe włości duchowe, zakorzenione w konkretnej topografii, pejzażu i środowisku" 23 .

${ }^{21}$ Por. Apokalipsa św. Jana $(13,18)$ : „Tu jest [potrzebna - J.S.] mądrość. Kto ma rozum, niech liczbę Bestii przeliczy: liczba to bowiem człowieka. A liczba jego: sześćset sześćdziesiąt sześć”.

22 J. Sadzik, dz. cyt., s. 28.

${ }^{23}$ S. Balbus, O poezji Tadeusza Nowaka [w:] T. Nowak, Wybór wierszy, przedm. S. Balbus, Warszawa 1973, s. 5. 
Nie chodziło tu jednak wyłącznie o literacką próbę uchwycenia istoty „ludowości”. Nowak nie był - co podkreśla Balbus - „poetą ludowym”. Jego postępowanie artystyczne wynikało nie „z ograniczeń właściwych prymitywnej sztuce folkloru" ${ }^{24}$, lecz było rezultatem samodzielnego i świadomego wyboru. Powtarzając za innym badaczem Rochem Sulimą, można zatem stwierdzić, że cechujące Nowaka:

dogłębne widzenie kultury ludowej (...) to nie tylko rodzaj zobowiązań wobec rodowodu, to również obowiązek pisarza wobec współczesnego świata. To powinność twórcy [który - przyp. J.S.] nie może pozostać obojętny wobec własnej cywilizacji ${ }^{25}$.

Świat opowiedziany w Psalmach to świat swojski, który Nowak dobrze znał, w którym żył i który go w znaczny sposób ukształtował. Jerzy Kwiatkowski pisze:

świat Nowaka zamknięty jest w kręgu realiów wiejskich, pejzażu wiejskiego. Nie jest to krąg współczesny: wyłaniający się z tych wierszy obraz to - w swej warstwie realnej - obraz wsi z czasów dzieciństwa poety lub dawniejszych ${ }^{26}$.

Kiedy więc Tadeusz Nowak jako młody chłopak debiutował w 1948 roku, wszedł „do literatury z bogatym dobytkiem tradycji ludowej”27. Wybór kostiumu biblijnego, w który przyobleka swoje (nie)psalmiczne wiersze jest wobec tego: ,jak najbardziej trafny z punktu widzenia praw poetyckiej ekspresji. Odwołując się do jednego z wielkich mitów ludzkości, Nowak automatycznie przydaje powagi i znaczenia swoim obsesjom i przeżyciom"28.

Psalm codzienny jest jednak o tyle wyjątkowy, iż - inaczej niż w Psalmach biblijnych - nie znajdziemy w nim nawet śladu uroku młodości, światła i ży$\mathrm{cia}^{29}$. Tu pojawiają się tylko dramatyczne doświadczenie życia oraz ludzka nędza, która jest równoważna codzienności. Bohater z wiersza nie może liczyć na boską pomoc ani opiekę. Jest właściwie zupełnie sam, niejako zawieszony w bezczasie.

\footnotetext{
${ }^{24}$ Tamże, s. 18.

${ }^{25}$ R. Sulima, Tadeusz Nowak. Zarys twórczości, Warszawa 1986, s. 8.

26 J. Kwiatkowski, dz. cyt., s. 209.

27 S. Balbus, O poezji Tadeusza Nowaka, dz. cyt., s. 6.

28 J. Kwiatkowski, dz. cyt., s. 211.

${ }^{29}$ J. Sadzik, dz. cyt., s. 26.
} 


\section{„...z głową wspartą na rękach...”}

Człowiek - bez imienia, bez nazwiska - siedzi przy stole „z głową wspartą na rękach”. Czy to po prostu skutek zbyt długiego picia? A może oznaka zmartwienia, smutku i życiowej niemocy? W końcu:

w głowie człowieka dom

(...)

w głowie człowieka żona

(...)

w głowie człowieka dzieci.

To rzeczy, wydawałoby się, ważne. Wyznaczają przecież kolejne etapy w cyklu ludzkiego życia, dają poczucie bezpieczeństwa i przynależności do wspólnoty. Są nośnikami pięknych wartości: miłości, przywiązania, obowiąz$\mathrm{ku}$, poświęcenia. Ale w wierszu czułość i delikatność współistnieją z brutalnym realizmem. To wyliczenie rudymentów domowego życia przerywa bowiem, powracający jak natrętne echo, wers: „kwaterka wódki śledź”. Rodzina zostaje więc odsunięta na dalszy plan, niczym (pusta już) butelka. W codzienności dominuje nałóg, powtarzany jak niekończący się rytuał, od którego bohater nie potrafi (bądź nie chce) się uwolnić. Utwór można zatem odczytać jako psalm (codziennie) żałobny. Przemawiają za tym nie tylko znana i mimowolnie narzucająca się czytelnikowi symbolika kości i szkła ${ }^{30}$, lecz także przejmujące odczucie samotności oraz braku nadziei. Tutaj egzystencja ludzka jawi się jako obraz nędzny i jałowy.

Jednak w wierszu, (znów) inaczej niż w niektórych Psalmach w Biblii, z ust człowieka siedzącego przy stole nie wyrywają się krzyk, wołanie, skarga do Boga, który, jak przekonuje Józef Sadzik, „nieosiągalny, niewypowiedziany, mieszkający w niebiosach jest jednocześnie Kimś wzruszająco bliskim, bliższym nawet niż człowiek samemu sobie, bezpośrednim w obcowaniu, dostępnym dla każdego" 31 .

Tutaj „świętość” wyrażona została poprzez zniewolonego anioła oraz ukrzyżowanego „Boga”. Jednak nawet wobec nich bohater liryczny nie wysuwa żadnych oskarżeń i nie czyni ich winnymi za swoją marną egzystencję, krążącą między kieliszkiem a butelką. Czy to nie dziwne? Przecież w takim beznadziejnym położeniu podobne żale byłyby czymś zwyczajnym. Mimo tego nie

30 Szkielet (kości) - brak życia i uczuć. Por.: „Bez serc, bez ducha, to szkieletów ludy” (Oda do mtodości Adama Mickiewicza); szkielet/kość jako śmierć. W. Kopaliński, dz. cyt., s. 167.

Szkło - kruchość kondycji ludzkiej; kieliszek - jako symbol zagłady, zatraty; „kieliszek” jako przeciwieństwo kielicha mszalnego na ołtarzu [w wierszu: stół - J.S.]; kielich - jako los, przeznaczenie. Tamże, s. 348-351.

31 J. Sadzik, dz. cyt., s. 21. 
słychać ich. Dlaczego? Być może odpowiedzią jest sposób, w jaki bohater ten został wykreowany przez poetę.

\section{Obok człowieka anioł. Obok człowieka Bóg}

W wierszu Nowaka świat nie jest poznawany „z zewnątrz” - nie jest też w żaden sposób uporządkowany ani ukierunkowany na określone cele. To świat odczuwany, doznawany, poznawany przez uwewnętrzniające uczestnictwo w otaczającej, szarej rzeczywistości. Ów biblijny lament okazuje się więc zbędny. Krzyk nie musi wydobyć się z krtani, by był równie mocno słyszalny i wymowny. Tym bardziej że: „w przeciwieństwie (...) do poetów, dla których metafora stanowi skrót myśli, u Nowaka metafora pełni jej funkcję. Inaczej mówiąc: Nowak myśli metaforami czy symbolami”32. Czy przemoc wobec anioła $^{33}$ i obraz ukrzyżowanego Boga nie mogą więc na swój sposób zastąpić skarg, wyrzutów i żali? Obok człowieka leży przecież:

związany drutem anioł

szkielecik śledzia szkło

obok człowieka leży

ukrzyżowany Bóg.

Biorąc pod uwagę powyższy kontekst, symbole te można, rzecz jasna, odczytać jako znaki oddalenia się człowieka od Boga, opuszczenia rajskiego Edenu i wydania na pastwę bezlitosnego życia. Pozostaje jednak pytanie, czy to Bóg odrzucił człowieka, czy - to człowiek pierwszy odwrócił się od Boga...

Niestety, strofa druga nie daje jasnej odpowiedzi. Wykorzystane w niej metafory budzą różne skojarzenia - od wojennych do biblijnych. Anioł jest przecież związany drutem. Słowo „kolczastym” nie pada, co prawda, w wierszu, ale - zważywszy na rok powstania Psalmu... - nie należy definitywnie negować takiej interpretacji. „Ukrzyżowany Bóg” potęguje tylko dramatyzm sytuacji lirycznej i wyostrza obraz przemocy dokonanej na niewinnych. Niekoniecznie musi też odsyłać do Odkupiciela, który, umierając na krzyżu, zapewnił ludzkości zbawienie. Być może związany boski wysłannik oraz Bóg na krzyżu to metafory zdradzonych, acz nie tylko religijnych, wartości.

${ }^{32}$ J. Kwiatkowski, dz. cyt., s. 214.

33 „Związany drutem anioł” - postać anioła zwykle kojarzona jest z dobrem (w opozycji do szatana) i pokorą wobec Boga; tutaj: anioł skrępowany może symbolizować między innymi próbę samostanowienia o sprawiedliwości przez człowieka oraz jego butę i (błędne) przeświadczenie o niezniszczalności. 


\section{Wieczerza, zdrada, śmierć?}

Jeżeli natomiast przyjąć, iż Psalm codzienny jest rodzajem ekfrazy, można pokusić się o odniesienia do trzech malarskich przedstawień scen biblijnych. Pierwszym byłaby ostatnia wieczerza, drugim - zdrada Judasza, trzecim ukrzyżowanie Chrystusa na Golgocie. Przecież Nowak:

penetruje rozmaite (...) połacie rzeczywistości. Trywialne realia życia wiejskiego, potoczne sytuacje ludzkie, obrazy o proweniencji biblijnej, obrzędowej, baśniowej, magicznej - występują u niego tuż obok siebie, wzajemnie się wymieniają (...), ujawniając w ten sposób swoje nowe znaczenia ${ }^{34}$.

Leonardo da Vinci, Jacopo Bassano, Andrea Castagno i Juan de Juanes to tylko niektórzy z wielkich mistrzów, których malarskie wyobrażenia ostatniej wieczerzy są podziwiane w muzeach na całym świecie. Rzecz jasna, Psalm codzienny nie opisuje wprost sceny z Biblii, lecz zawarte w nim aluzje zdają się (przynajmniej w jakimś stopniu) uprawomocniać tę interpretację.

$\mathrm{W}$ wierszu akcja również toczy się przy stole. Siedzi przy nim człowiek, a na blacie leży śledzik/ szkielecik śledzia i kwaterka wódki/ szkło.

Być może owa ryba i „ekwiwalent” wody są bardzo dalekim echem, ukazanych z bolesną ironią, chrześcijańskich symboli: ryby (Chrystus dzielący na pustyni chleb i ryby, a także ryba jako znak pierwszych chrześcijan) oraz wody (oznaczającej między innymi chrzest, oczyszczenie z grzechów i przemianę duchowa). Ponieważ jednak nie są już nośnikami wartości sakralnych - posiłku przy stole nie spożywa się też na pamiątkę męki, śmierci i zmartwychwstania Chrystusa. Teraz to po prostu zwykła kolacja, obiad bądź śniadanie - mistyczne treści ostatecznie odeszły w zapomnienie. Liczy się doczesność i (wątpliwe, gdyż prowadzące do zguby) samostanowienie ludzi o własnej moralności. Zwłaszcza że: „obok człowieka leży/ trzydzieści groszy reszty” - niczym trzydzieści srebrników, które otrzymał zdrajca Chrystusa.

Tak jak Judasz za garść srebrnych monet wydał Zbawiciela, tak człowiek z wiersza za marne: kwaterkę wódki i śledzia zdradza wszystko to, co jest (było) dla niego najważniejsze: dom, żonę, dzieci. Nałóg stał się sensem jego egzystencji. Człowiek nie ma zatem szans na znalezienie drogi powrotu - butelka za butelka, zakąska za zakąską - nieprzerwanie, coraz silniej zatraca się w skropionej wódką, szarej i bezcelowej codzienności.

Dla tego człowieka nie ma już znaczenia, że obok „leży związany drutem anioł” i „ukrzyżowany Bóg”. Niemniej ta scena, podobnie jak wcześniejsza, może budzić skojarzenia z Nowym Testamentem. Nie bez powodu przecież są tu ukazane trzy osoby, wśród których - jedna pozostaje zawsze w centrum. Wizję tę można zatem odczytać jako swoistą reinterpretację Golgoty, gdy na krzy-

${ }^{34}$ S. Balbus, O poezji Tadeusza Nowaka, dz. cyt., s. 11. 
żach obok Chrystusa zawisło dwóch złoczyńców. Jeden z nich uwierzył i jeszcze przed śmiercią nawrócił się. Drugi na wieki pogrążył się w czarnej otchłani.

W Psalmie codziennym sytuacja ta zdaje się odwrócona: w centrum siedzi grzesznik, który dla nałogu zdradził prawdziwe życiowe wartości, a z jego prawej i lewej strony leżą: skrępowany anioł i umęczony Bóg. Oboje pokonani, zhańbieni. Ich ofiara nie przyniesie nikomu zbawienia. Człowiek nie uwierzy, jego los się nie odwróci. Paradoksalnie - kielich goryczy przywołany w modlitwie Chrystusa w ogrodzie oliwnym - tutaj, pełen wódki, jest bardzo pożądany i być może zyskałby nawet znaczenie pozytywne, gdyby nie to, że prowadzi do zatracenia. Człowiek jest bowiem zbyt zaślepiony tym, że na stole został już tylko „szkielecik śledzia” i puste szkło, by przejmować się czymkolwiek innym...

\section{„Szkielecik śledzia szkło”}

Powyższe odczytania są, rzecz jasna, tylko sugestiami, pozwalającymi spojrzeć na wiersz Nowaka w inny niż zazwyczaj sposób. Niezależnie od tego, czy czytelnik, tak jak ja, dostrzeże podobieństwo Psalmu... do wybranych scen biblijnych, jedno pozostaje pewne. Z każdym kolejnym wersem bohater utworu coraz bardziej „powszednieje”, to znaczy zatapia się w codzienności - a ponieważ równa się ona nałogowi, wyższe wartości odchodzą w zapomnienie. Widać to wyraźnie już w samej konstrukcji wiersza.

Pierwsza strofa jest jeszcze przepełniona nadzieją, że człowiek siedzący przy stole zrozumie swoje błędy. Wersy: od trzeciego do ósmego przypominają wyliczankę, w której wybór toczy się między domem, rodziną a jednym $\mathrm{z}$ siedmiu grzechów głównych - nieumiarkowaniem w jedzeniu i piciu. Warto również zwrócić uwagę na to, że powtórzony trzykrotnie ciąg: „kwaterka wódki śledź” zawiera po sześć zgłosek ${ }^{35}$.

W strofie drugiej nastrój zmienia się. Teraz człowiek przy stole coraz bardziej zatraca się w nałogu. Dom, żona i dzieci w ogóle nie zaprzątają już jego myśli. Pojawia się, co prawda, anioł i Bóg, ale pierwszy z nich stał się ofiarą buntu człowieka i - zamiast symbolizować pokorę i wiarę - wyraża już tylko swoją niemoc. Bóg natomiast, nie królujący, ale ukrzyżowany, ukazany zostaje w chwili niemocy. Psalm codzienny, który w miarę czytania przekształca się w rodzaj psalmu żałobnego (upamiętniającego jałowy żywot człowieka pozostającego wiernym nałogowi), jest też więc w pewnym sensie bluźnierczy. Nie powinno to jednak dziwić, gdyż postępowanie człowieka, który wybrał „trzydzieści groszy reszty" i kwaterkę wódki, śledzia, musiało doprowadzić do wystąpienia przeciwko nakazom Najwyższego.

${ }^{35}$ Tutaj szóstka, jak chce tradycja, byłaby więc złowieszcza, prowadząca do tragicznego końca. Podobnie jest w drugiej strofie („szkielecik śledzia szkło”) i kończącym wiersz dwuwersie. 


\section{Podsumowanie}

Proponowane interpretacje, jak już wspomniałam, to tylko niektóre z wielu możliwych odczytań, do jakich prowokuje lektura Psalmu codziennego Tadeusza Nowaka. Ten bowiem, niesłusznie zaklasyfikowany jako „wiejski” twórca, „bynajmniej nie chce złagodzić siły swych przeżyć: chce je przetłumaczyć. Okrężną drogą powinny dotrzeć one do czytelnika z siłą nie mniejszą, lecz spotęgowaną jeszcze działaniem sztuki" ${ }^{36}$. Jednocześnie Nowak w każdym ze swych Psalmów demaskuje wszelkie nagromadzone przez lata sztuczne uładzenia „faktycznych rozdźwięków i wskrzeszenia umarłych wartości” ${ }^{37}$. A ponieważ jako ostatni bard XX wieku każdorazowo tworzy niesłychanie precyzyjne, przemyślane oraz konsekwentne konstrukcje artystyczne - nadając przy tym nowe sensy codzienności oraz całej folklorystycznej „rupieciarni” i nobilitując kulturowe „odpadki” do roli zapomnianych skarbów, jego wiersze jeszcze długo roztaczać będą aurę niezwykłości i skłaniać do ponownego przemyślenia tego, co wydawało się oczywiste.

\section{Bibliografia}

Balbus S., Opoezji Tadeusza Nowaka [w:] T. Nowak, Wybór wierszy, przedm. S. Balbus, Warszawa 1973.

Balbus S., Poezja w czasie marnym (O metafizyce i historiozofii poezji Tadeusza Nowaka), Kraków 1992, http://biblioteka.kijowski.pl/nowak\%20tadeusz/balbus\%20o\%20nowaku.pdf, dostęp: 15.04.2017.

Balbus S., Tadeusza Nowaka psalmy mitosne [w:] Nowy Nowak (Tadeusz), red. J. Olejniczak, R. Knapek, Katowice 2016.

Balbus S., Zagtada gatunków [w:] Polska genologia literacka, red. D. Ostaszewska, R. Cudak, Warszawa 2007.

Brudnicki J., Tadeusz Nowak, Warszawa 1978.

Kopaliński W., Siedem; Sześć; Szkielet, Szkto; Kieliszek [w:] tegoż, Stownik symboli, Warszawa 1991.

Kwiatkowski J., Magia poezji (O poetach polskich XX wieku), Kraków 1995.

Nowak T., Wiersze wybrane, Warszawa 1978.

Pustkowski H., Psalm [w:] Stownik rodzajów i gatunków literackich, red. G. Gazda, S. Tynecka-Makowska, Kraków 2006.

Sadzik J., O psalmach [w:] C. Miłosz, Ksiegi biblijne. Przektady z jezyka greckiego $i$ hebrajskiego, Kraków 2003.

Sulima R., Tadeusz Nowak. Zarys twórczości, Warszawa 1986.

${ }^{36}$ J. Kwiatkowski, dz. cyt., s. 211.

37 S. Balbus, O poezji Tadeusza Nowaka, dz. cyt., s. 14. 